\title{
Population Structure and Habitat Condition of Lola Snail (Trochus niloticus. Linn) at East Coast, Saparua Island, Saparua Subdistrict, Central Maluku District
}

\author{
S. F. Tuhumury \\ Faculty of Fisheries and Marine Science Pattimura University \\ Mr. Chr. Soplanit Street, Poka Campus, Ambon, Indonesia \\ Tel: 62-911-382-5060 Fax: 0911-3825062 E-mail: sftuhumury@yahoo.co.id
}

Received: April 1, 2013 Accepted: April 17, 2013 Published: June 25, 2013

doi:10.5296/jee.v4i1.3916

URL: http://dx.doi.org/10.5296/jee.v4i1.3916

\begin{abstract}
Lola Snail (Trochus niloticus) was an organism threatened to extinct due to excessive exploitation. In addition to the higher usage rate of lola snail, the catch of fish around habitat of lola snail was also the cause of the decreased population of the snail. Therefore, information about population structure and coral reef condition which became the habitat of lola snail was absolutely important. Research was conducted at eastern coastal waters of Saparua Island, Saparua Subdistrict, Central Maluku District, from January to June of 2010. The sampling of lola snail and the observation of coral reef were using Line Intercept Transect (LIT), while the identification of age structure was using FISAT II Version 0.3.1. Result of research indicated that the potentiality of lola snail resources at eastern coast of Saparua Island was 7,749,111 individuals. Maximum catch rate was 3,874,555 individuals. The allowable catch rate was 3,099,644 individuals. Asymptote length $(\mathrm{L} \infty)$ and coefficient of growth $(\mathrm{K})$ for lola snail were 0.52 per year. K-value indicated fast growth rate at short age, which was 16 months or 1.4 years. Total Mortality Rate $(\mathrm{Z})$ was 2.66 , while natural mortality (M) was 1.39. Catch mortality (F) was 1.27 , and optimum exploitation rate was 0.48 . Coral reef condition in eastern coast waters at Saparua Island was ranging from moderate to good condition.
\end{abstract}

Keywords: Trochus niloticus, coral reef, population structure, Saparua Island 


\section{MlMacrothink}

\section{Introduction}

A marine resource that experienced over-fishing was lola snail (Trochus niloticus L.). The shell of lola snail had important economic value as the export commodity because it was used as raw material of various industries such as the mixture of car paint, cloth button, and jewelry. The meat of lola snail was used for animal protein sources. Because of higher economic value of lola snail, the exploitation against this commodity was increased. In some regions, the population of lola snail was in the critical condition due to the higher intensity of catch (; Nash, 1985; Arifin, 1993; Crowe et al., 2001; Leimena et al., 2007).

The requirement of world market for lola snail shell was increasing. The production of world lola snail shell in 1990 was estimated for 4000 tons/year. Of this number, $70 \%$ were coming from Pacific countries while the rest was from Southeast Asia and Indonesia (FAO, 1992). In 1998, world market demand for lola snail shell reached 7000 tons/year with range from 50-60 millions American dollars (Lawrence, 1998). Lola snail that was hauled and traded in Maluku had shell diameter 5.0-13.0 cm (Arifin, 1993). Meanwhile, lola snail reached its first sexual maturity in the size between 5.0-7.0 $\mathrm{cm}$ or at the age of 2-3 years old (Nash, 1985; Foale, 2000). Indeed, the smallest size of lola snail hauled in Maluku waters was estimated as the new spawning adult individual. Because the catch of lola snail with shell diameter smaller than $7.0 \mathrm{~cm}$ was still continued, it was worried that the life development of lola snail to the maturity with spawning readiness would be limited. It was also not surprised if Trochus population decreased with the potentiality of extinct in the future.

The decreased population of Trochus was closely related to habitat damage, explosive-based catch, coral reef collecting for building ornament, and land-based pollution (Indrawan et al., 2007). The use of explosive and the collection of coral reef might damage coral reef ecosystem which played important ecological roles (nursery, feeding and spawning grounds) for various life biota, including lola snail. Coral reef ecosystem was a habitat for lola snail. However, if this ecosystem was damaged, it would influence the population of lola snail.

Considering this research background, the objective of research was to acknowledge the population structure and the coral reef condition which became the habitat of lola snail in the east coast of Saparua Island.

\section{Method of Research}

\subsection{Time and Place of Research}

Research was conducted in east coast waters of Saparua Island, Saparua Subdistrict, Central Maluku District from January to June 2010 (Figure 1). 


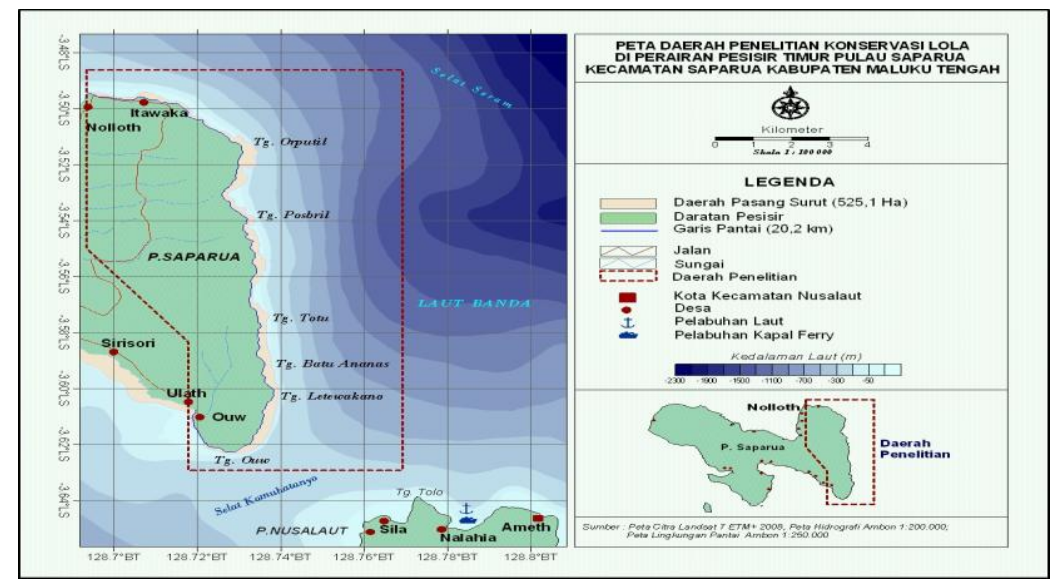

Figure 1. Research Location Map

\subsection{Sampling of Lola Snail and Coral Reef Condition}

The sampling and observation of lola snail and coral reef in the 5-6 $\mathrm{m}$ depth from the edge of coral reef were using LIT Line Intercept Transect (LIT) with few modifications. Lola snail was put into plastic batch, and its basal diameter and its shell height were measured using digital calipher. Coral reef data were collected and analyzed in "Life Form" Program.

The processing of LIT data was employing Life Form Program to understand the density, potentiality and usage rate, and therefore, MSY (Maximum Sustainable Yield) and JTB (Allowable Catch Rate) were obtained.

\subsection{The Growth of Trochus Niloticus}

Many age groups (cohorts) of lola snail (T. niloticus) were known by analyzing the lola snail with Model Class Progression Analysis (MCPA) in FiSAT Program.

Based on size frequency data, some age groups in the lola population were determined during sampling. Data of the number of lola snail individuals in each age group in east coast waters were collected through the separation analysis over the frequency distribution of shell diameter, using Bhattacharya Method (in FISAT II Program Version 0.3).

Lola snail age from the birth $\left(\mathrm{t}_{0}\right)$ was estimated to get information of lola snail compared to the information of spawning peak. The rate of $\mathrm{t} 0$ could be obtained through $\mathrm{K}$ and $\mathrm{L} \infty$ rates in the equation $\log 10\left(-\mathrm{t}_{0}\right)=-0.3922-0.2752 \log 10 \mathrm{~L} \infty-1.038 \log 10 \mathrm{~K}$ (Pauly, 1980), where $\mathrm{K}$ was coefficient of growth, L $\infty$ was asymptote length and t0 (early parameter) was age when the length was zero.

Natural life interval (longevity) was life timing interval for species. Pauly (1982) defined it as a life timing interval that was achieved by a species in a cohort until $99 \%$ of cohort member reached the natural dead. The equation Von Bertalanffy was further explained to produce an equation $\mathrm{t}=\log 10(1-\mathrm{Lt} / \mathrm{L} \infty) / \mathrm{K}-\mathrm{t} 0$. If maximum length $(\mathrm{L} \max )=0.95(\mathrm{~L} \infty)$ was included into the equation, then the longest age (life span) of lola snail was obtained, precisely L max $=2.9957 / \mathrm{K}+\mathrm{t} 0($ Pauly, 1980). 


\section{Macrothink}

\subsection{Mortality Estimation}

Total mortality estimation (Z) was estimated using catch curve, or catch curve (Ricker, 1975). Few modifications were made similar to Pauly (1980 a), and Beverton and Holt's formula (1956) was also used. Natural mortality (M) was estimated using empirical equation used by Pauly (1980 b).

\section{Result}

\subsection{Density}

Total density data of lola snail population were 58,714 individuals/ha with average density of 9,786 individuals/ha. The highest lola snail density was found in June 2010, precisely 14,714 individuals/ha, followed by April 2010 with 12,571 individuals/ha. The lowest density was observed in February 2010 with the density of 4,857 individuals/ha (Figure 2).

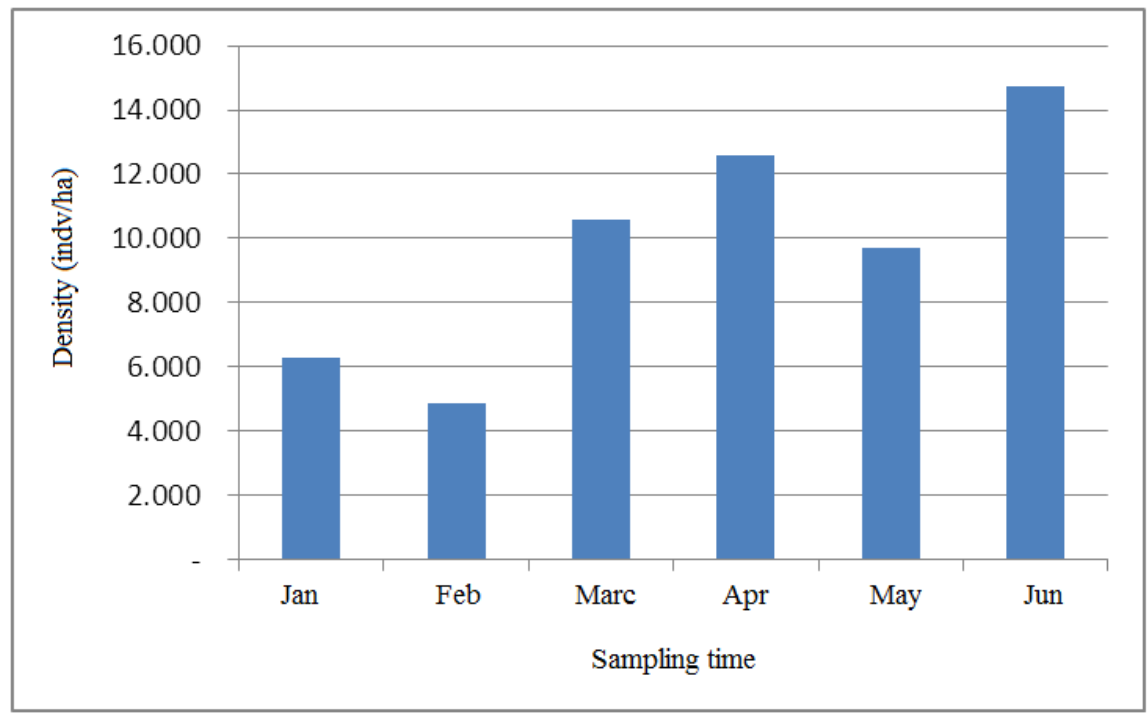

Figure 2. The Density of Lola Snail in East Coast of Saparua Island, based on sampling period

\subsection{Potential and Usage Rate}

The potentiality total of lola snail resources during six times of sampling at east coast waters of Saparua Island was 7,749,111 individuals. The highest potentiality rate of lola snail was observed on June 2010 with 1,941,991 individuals (Figure 3). Based on this potentiality, the estimation of maximum sustainable yield (MSY) for lola snail individual at east coast waters of Saparua Island was 3,874,555 individuals with allowable catch rate (JTB) of 3,099,644 individuals. 


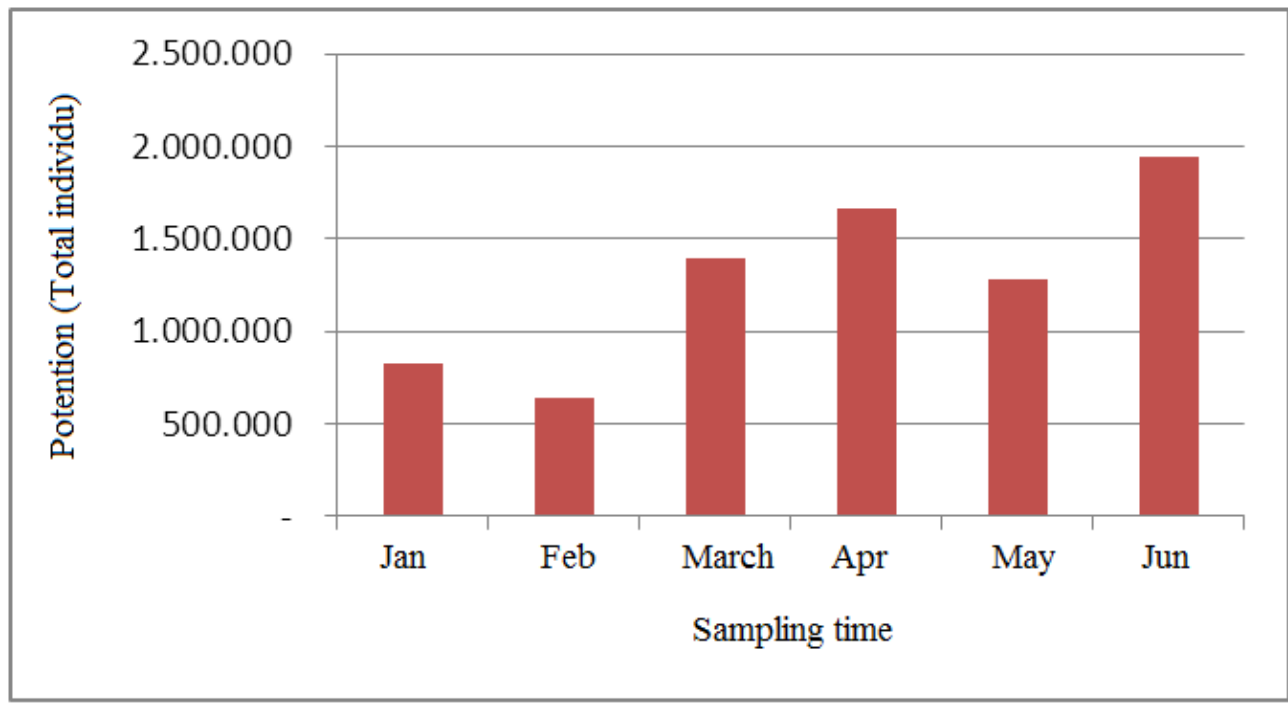

Figure 3. The Potentiality of Lola Snail Resources based on Sampling Period at East Coast of Saparua Island

The relationship between width and height of lola snail shell was visualized in the form of graphic and regression equation (Figure 4). The ratio average between shell's width and height was 1.8 in the regression equation $\mathrm{y}=0.8207+0.6780$ with coefficient of determination $\mathrm{R} 2=0.8586$. Ratio and regression equation were parameters used to help the identification of lola snail (Trochus niloticus).

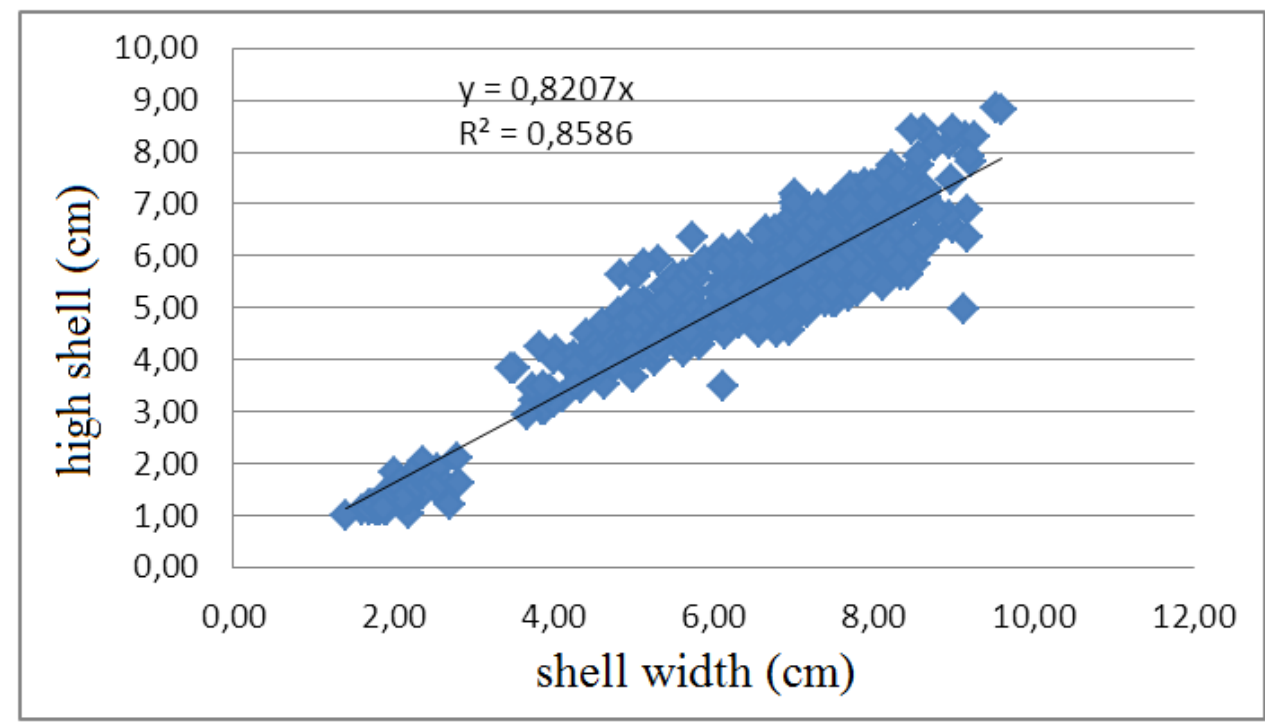

Figure 4. Morphometric Relationship of Lola Snail (T. niloticus) Shell

\subsection{Size Distribution}

Individual grouping based on shell diameter size was shown in histogram (Figure 5). Histogram of the class of lola snail shell diameter size indicated that the population of lola snail at east coast waters of Saparua Island was grouped into ten size classes. 


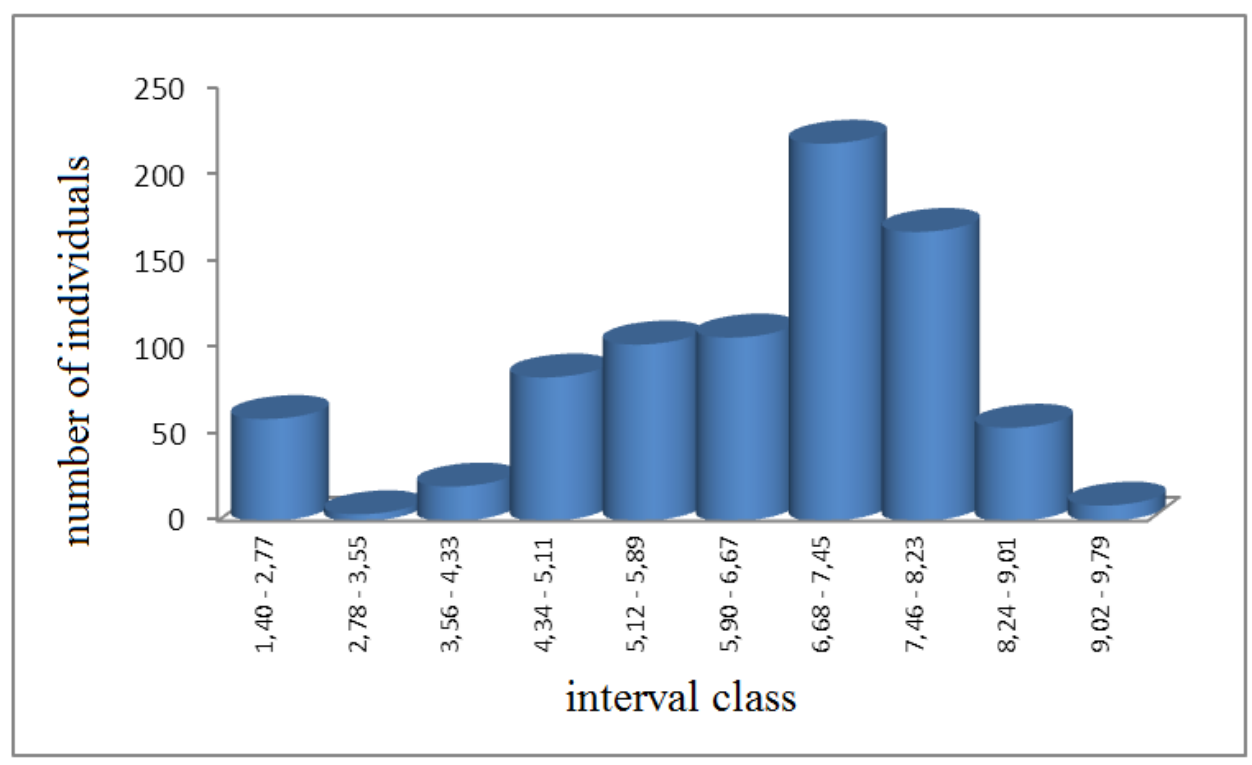

Figure 5. The Number of Lola Snail (T. niloticus) Individuals at Each Size Class Interval

\subsection{Growth Analysis}

A graphic of monthly frequency distribution of shell width (January - June 2010) was displayed in Figure 6. The curve of lola snail growth was presented in Figure 7. The comparison of coefficient K/year was indicating that lola snail in east coast waters of Saparua Island, Maluku, had faster growth than lola snail in other waters.

Individuals with $16.7 \mathrm{~cm}$ size were very few. It was caused by high exploitation rate by the community, and therefore, the size over $0.8 \mathrm{~cm}$ was hardly found.

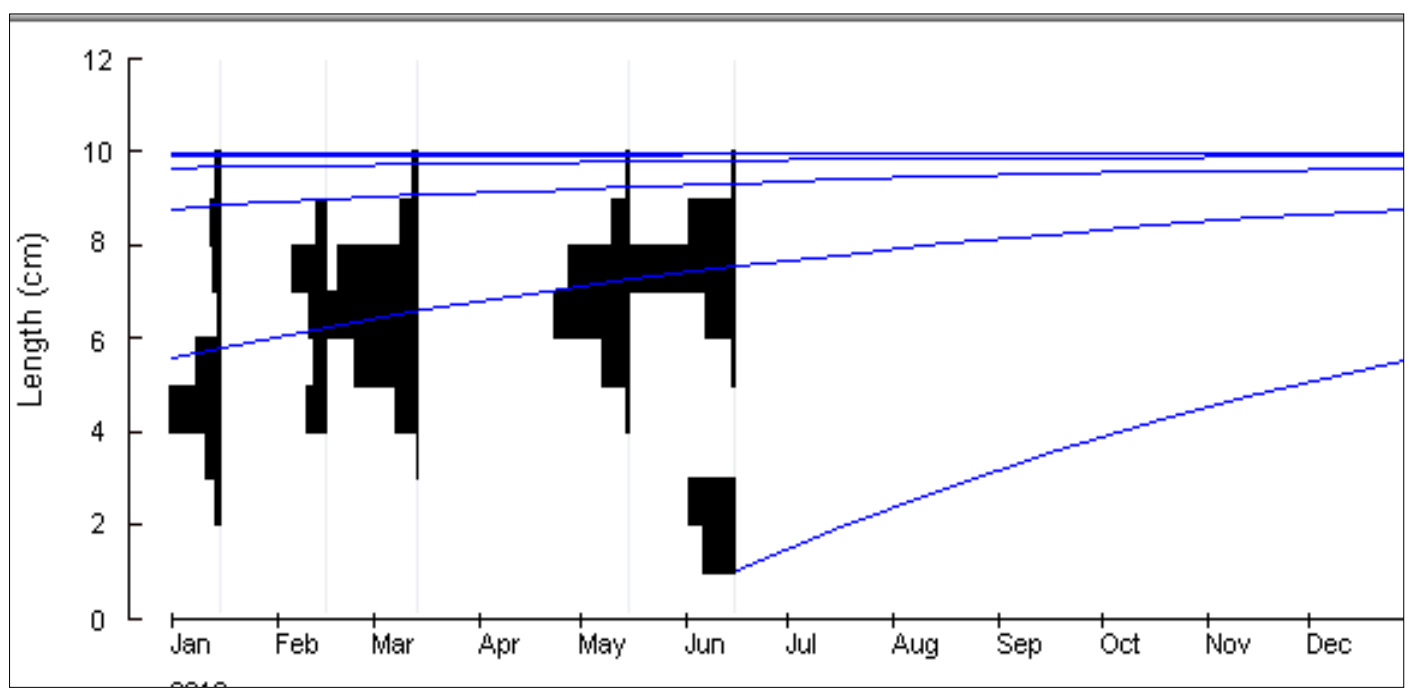

Figure 6. The Graphic of Frequency Distribution of Lola Snail Shell in Period January-June 2010 


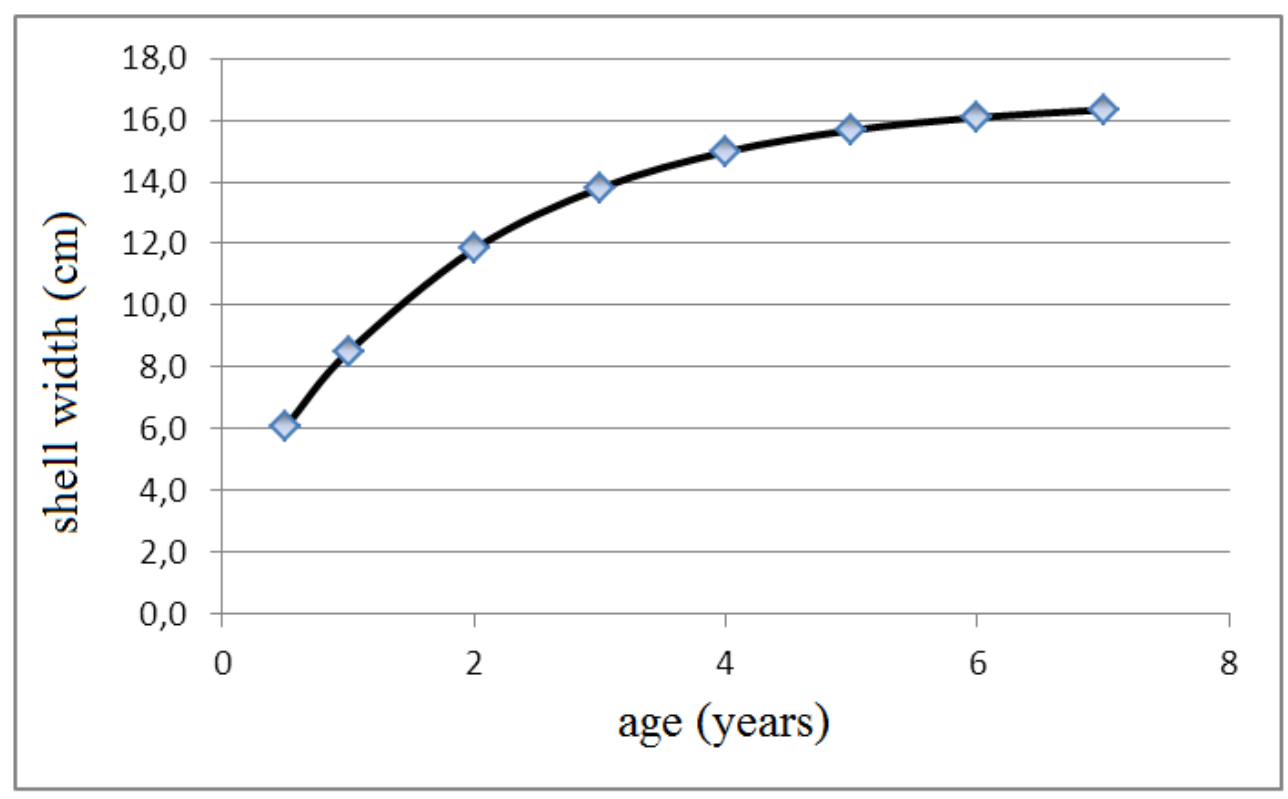

Figure 7. The Growth Curve of Lola Snail (T. niloticus) in east coast waters of Saparua Island Based on Von Bertalanffy equation, maximum age for lola snail was between 6 and 7 years old.

\subsection{Mortality}

Result of mortality research based on growth parameters (K, L $\infty$ and t0) was shown in Table 1. Total mortality rate $(\mathrm{Z})$, consisting of natural mortality rate $(\mathrm{M})$ and catch-caused mortality rate $(F)$, was relatively high.

Table 1. Some parameters of lola snail (T. niloticus) mortality in east coast waters of Saparua Island

\begin{tabular}{|l|c|}
\hline \multicolumn{1}{|c|}{ Parameter } & Trochus niloticus \\
\hline Total Mortality Rate (Z) & 2,66 \\
Natural Mortality Rate (M) & 1,39 \\
Catch MortalityRate (F) & 1,27 \\
Optimum Eksploitation Rate (E) & 0,48 \\
\hline
\end{tabular}

\subsection{Coral Reef}

\section{- Composition of Coral}

Species, genus and family of coral at east coast waters of Saparua Island were displayed in Figure 8. 


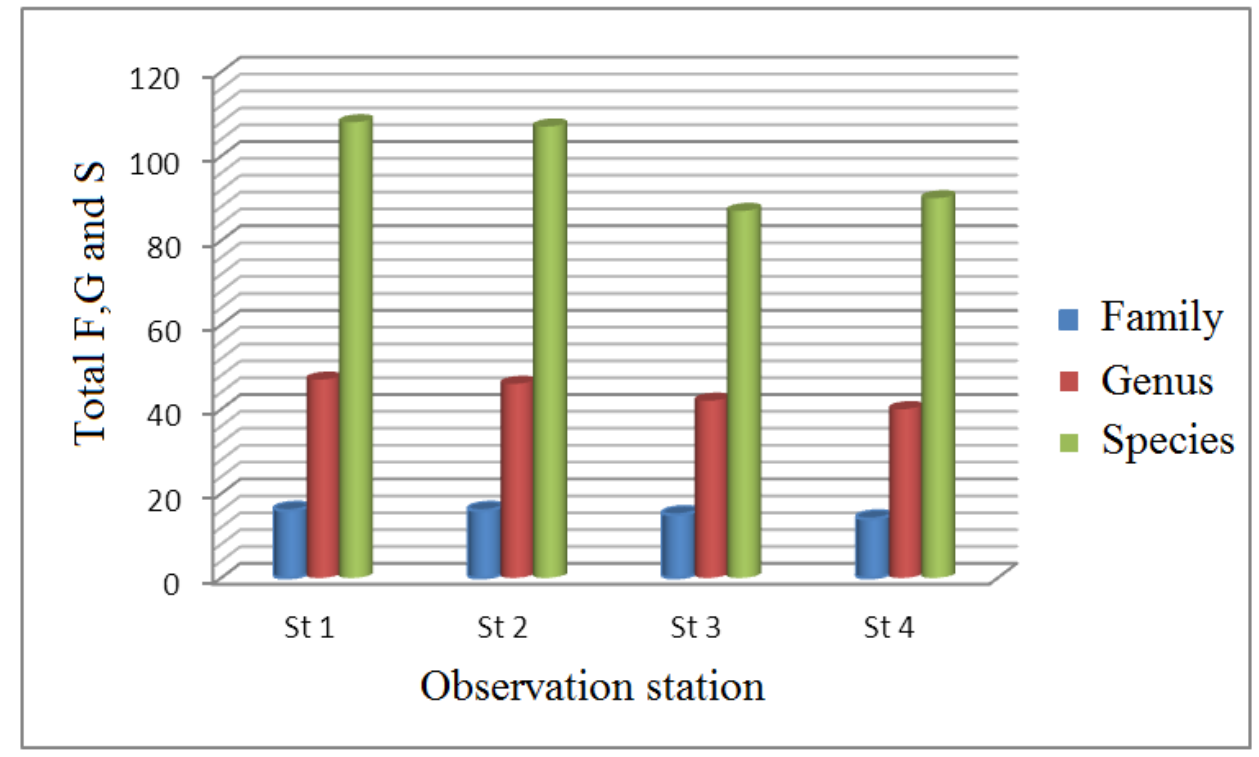

Figure 8. Species, Genus and Family of Coral at East Coast Waters of Saparua Island

Coral species dominating coral reef waters was Non Acropora species, especially with individuals with massive and sub massive growth such as Porites genus (Porites lutea, P.cylindrica, P. annae, P. lobata and Porites lichen), Favia genus (Favia rotundata, F mathaii), Favites genus (Favites abdita, F.flexuosa), Diploastrea genus (Diploastrea heliopora), and Goniastrea genus (Goniastrea pectinata). Coral reef waters might be rather opened location site against wave strike, and therefore, this coral species with well growth in this site were massive, sub massive and encrusting species because they grew to follow the hard substrate base. At Ihamahu location, four coral species dominating the site were Mycedium elephantotus, Echinophyllia aspera, Echinopora lamelosa and Seriatopora histrix. These species grew on rather fine substrate which consisting of sand and coral fracture.

The damage of coral was mainly caused by fish catch activity by fisher using destructive fishing gear device such as explosive material at station 1-3. It seemed that coral fracture was widely distributed around transect location for these three locations.

\section{- Closure Component of Coral Reef Ecosystem}

Main component of benthic life form consisted of life corral, dead corral, algae, other fauna and abiotic fauna (sand, rubble silt and rock), that were used to measure coral reef condition. Result of research showed that the highest percentage of life corral at Station 1 was $62.42 \%$ and it was followed by Station 4 with $50.91 \%$ and Station 2 with $48.23 \%$. The lowest was found at Station $3(43.73 \%)$. The detailed percentage of each benthic component at transect location was observed in Figure 9. The coral optimization rate criteria were proposed by The Minister of Life Environment of Republic of Indonesia Number 4 of 2001. Station 1 and Station 4 had coral condition in the good category. The moderate category was found at Station 2 and 3. 


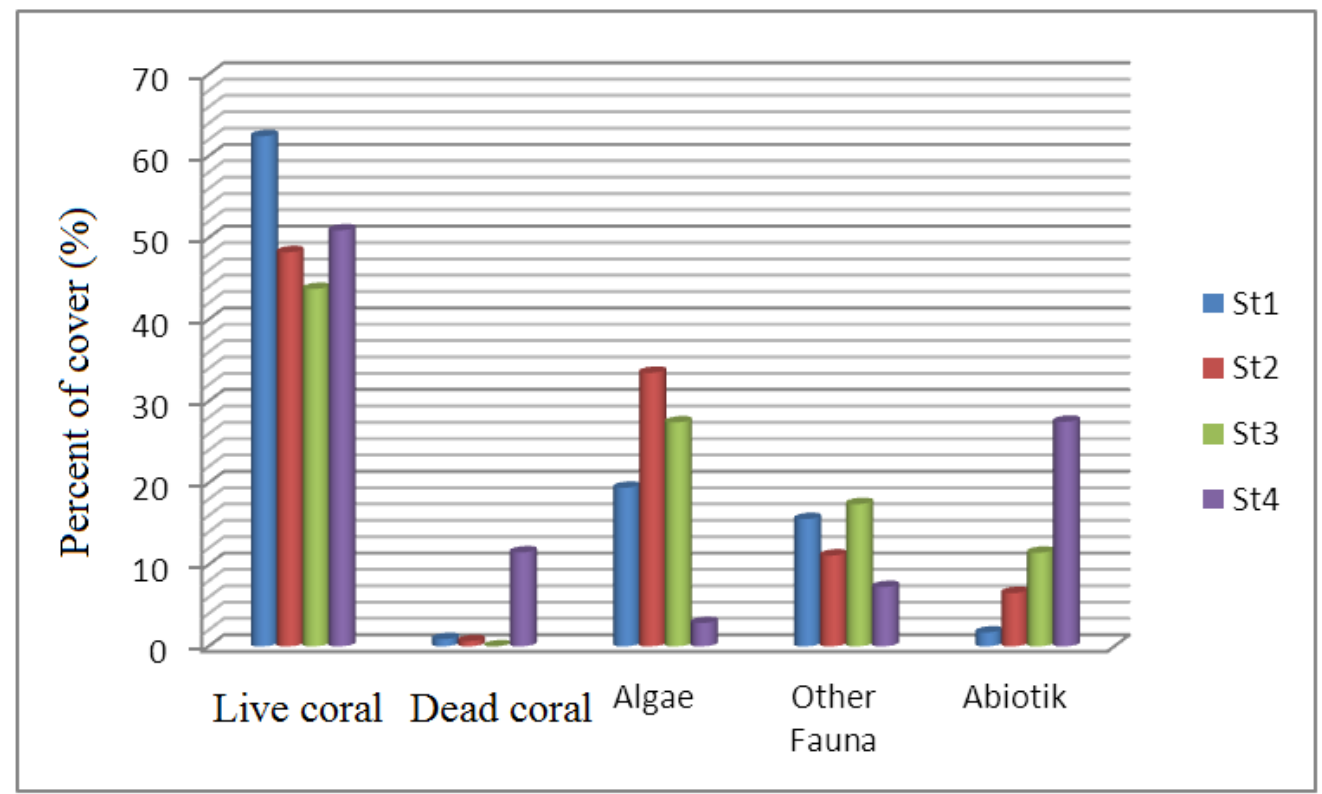

Figure 9. The Percentage of Coral Coverage in East Coast Waters of Saparua Island

In Figure 9, it was shown that algae component, especially turf algae, was relatively high at Station 2 and 3, particularly to $27.41 \%-33.48 \%$. This condition was a supporting factor for the existence of lola snail (Trocus niloticus) where the snail was mostly found in transect area of $140 \mathrm{~m}^{2}$ with $44-114$ individuals in average.

- Distribution Zoning and Coral Growth

Growth and distribution of the coral at each observation site had similar characteristics where the morphology of coast from the edge included coconut, shrub and mangrove. Sand and sea grass, and reef flat, reef margin, and sea chasm, were also considered. The growth of the coral started from 90-110 m from the coast line. The location with this characteristic was described in Station 1 and Station 3.

The location of Station 1 and Station 3 had a mixing substrate, such as the mixing of sand-rock, the piece of seagrass-covered rock, the mixing of rock and dead rock, and the mixing of rock, life rock, and sand. The position of coral reef distribution was shown in Figure 10, 11 and 12. 


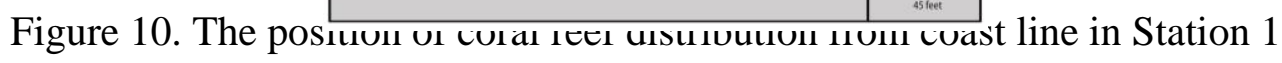

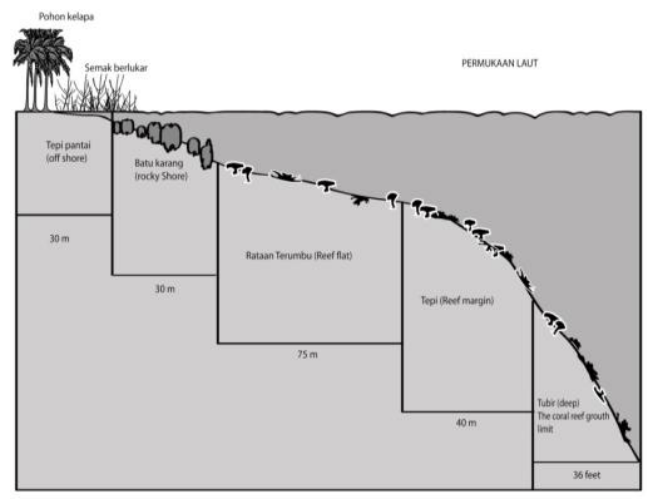

Figure 11. The position of coral reef distribution from coast line in Station 2

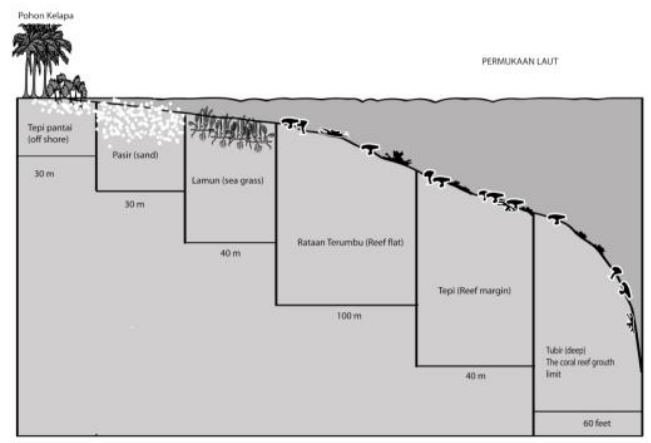

Figure 12. The position of coral reef distribution from coast line in Station 3

The zoning and the morphology of the coast as shown in Station 4 (Figure 13) were dominated by the edge of coast covered by coconuts and shrubs. The coast area included dominantly sand, and followed by reef flat that was vertically grown to less than $200 \mathrm{~m}$ height. Not all corals at reef flat grew to cover substrate but it was also surrounded by white sand. The measurement of component in covering substrate involved abiotic components (sand) which reached $27.48 \%$. This condition reduced life coral percentage but if it was seen 
from coral health, the condition of coral was very good. The narrow reef margin was less than $20 \mathrm{M}$, and then, rock growth reached the depth of $12 \mathrm{~m}$ or 36 feet.

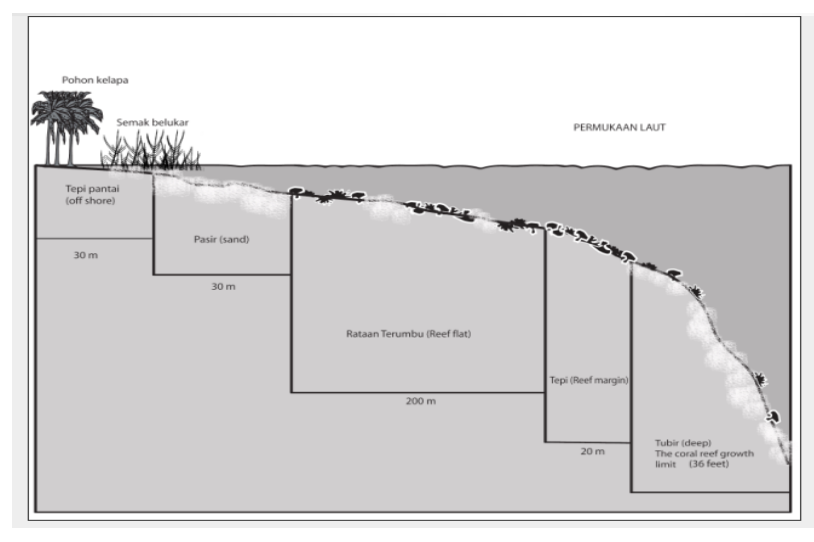

Figure 13. The position of coral reef distribution from coast line at Station 4

\section{Discussion}

Naturally, lola snail density in certain waters was affected by some factors such as substrate type, food stock, wave toss strength, and waters depth. Lola snail always lived within coral waters with the abundance of micro algae as food. The waters in lola snail habitat coast referred to open waters with great wave toss (Moorhouse, 1932; Rao, 1937; Heslinga et al., 1984; Hahn, 1989). The density and distribution of lola snail based on waters depth were related to the supply of micro algae (Moorhouse, 1932; Nagao, 1944). In Saparua Island, lola snail was found in east and south waters that were facing directly toward free ocean with stronger wave toss than other part of island.

The density of lola snail in east coast of Saparua Island was lower than the population of lola snail in some other locations, including Big Kei Island, Banda Island, and Tayando Island which covered 30,000 individuals/ha (Arifin, 1993). The lower density of lola snail in east coast of Saparua Island was estimated as caused by the continuing collection of lola snail without conservation. The difference of lola snail density based on sampling (6 months collection) was mainly caused by the different method by community in collecting lola snail. Mostly, the community freely exploited lola resources in the nature. Therefore, the population of lola snail was given little chance to do its own recovery and recycle. The wellbeing of a population was influenced by the addition of individual into the population. A sasi system must be redeveloped because it was a traditional conservation method in Saparua Island which would be useful to recover the condition of lola snail resources.

Lola individual was mostly found as juvenile group, and the older individual was in the moderate number. The size of juvenile lolasnail indicated the readiness of lola to do first spawning to become larvae. At Low Isles (Pacific), female lola snail reached sexual maturity in the age of two years old, precisely when the shell diameter was between $5-6 \mathrm{~cm}$ (Moorhouse, 1932). Female snail at Andaman waters reached sexual maturity at 3 years old with shell diameter $9 \mathrm{~cm}$, while male snail had shell diameter between 6 and $7 \mathrm{~cm}$ (Armithalingam, 1932; Rao, 1937). Distribution of diameter of lola snail at Saparua Island 
was ranging from $2.32 \mathrm{~cm}$ to $9.68 \mathrm{~cm}$ with six size classes. The individual with size diameter 2.31-5.70 cm was greatest in number, while the individual with size diameter 7.14-9.95 cm was smallest in number (Leimena, 2004). Result of research by Ponia et al., (1997) at Cook Island (Australia) and Trianni (2002) at Saipan Island (Pacific) indicated that lola snail at both locations had shell diameter ranging from 7 to $13 \mathrm{~cm}$. Meanwhile at Cartier Reef (Australia), it was dominated by individual with shell diameter greater than $7 \mathrm{~cm}$ (Smith et al., 2002).

Sexual maturity could be found in size diameter $6.0 \mathrm{~cm}$ (Chauvet et a.l, 2004). Therefore, based on growth curve (Figure 6), Trochus niloticus in east coast waters of Saparua Island could reach mature size at 6 months age. Minimum lola snail size that was found in Palau Island waters was $7.6 \mathrm{~cm}$ which reached at 2 years old of age (Heslinga et al, 1983). At Guam, this size was reached at 3 years old of age (Smith, Bour and Gohin, 1982 dalam Heslinga et al 1983). At Old Olilit Village, West Southeast Maluku District, this size even required 1.5 years (Suwartana et al., 1985). Result of current research showed that at east coast waters of Saparua Island, this size could be attained at the time less than 1 year. According to Dwiponggo (1982), growth speed was affected by food supply in the environment where lola snail lived because growth speed could be different annually, especially for youth lola snail which had faster growth than adult lola snail. Natural mortality rate, however, was little higher than adult lola snail. It related to some biological conditions such as predator, disease or biotic interaction including eutrophication (Del Norte-Campos, 2004 in Natan, 2008). Indeed, the usage rate or the catch rate was also relatively higher such that it influenced the mortality rate of the catch.

Coral growth was greatly influenced by current and wave patterns from Banda Sea. Verwey as quoted in Sukarno et al (1981) said that current was necessary to supply sufficient oxygen for the fauna in the coral reef. However, too strong current might influence the growth of coral, precisely decelerating the growth speed. Barnes (1987) mentioned that if subjected to higher wave energy, coral reef or coral had slower growth but greater compaction and density than when it subjected to moderate wave energy. In the calm water which contained mud or sand, coral animal was difficult to clean themselves from mud precipitation or sand coverage (Nontji, 1987). Nybakken (1992) added that in general, coral reef grew in regions with great wave. The result of observation over coral reef profile and coral types, and also substrate condition, showed that all four stations at east coast waters of Saparua Island were the main region of lola snail (Trochus niloticus) distribution.

\section{Conclusion}

The potentiality of lola snail resources at eastern coast of Saparua Island was 7,749,111 individuals, with the highest potentially found on June (1,941,991 individuals). Maximum catch rate was 3,874,555 individuals, while the allowable catch rate was 3,099,644 individuals. Result of analysis of the distribution of lola snail size indicated that lola snail group was mostly consisting of young individual. Therefore, in harvesting lola snail Trochus niloticus, it should be better to ascertain when the harvest to be carried out or when the harvest not to be conducted. A model to manage lola snail (Trochus niloticus) must be 
developed to improve the sustainability of this organism. The composition of coral reef at east coast waters of Saparua Island included 111 species, but this number was lower than other places at Maluku. Coral reef at east coast waters of Saparua Island remained in the range of moderate to good conditions.

\section{Acknowledgement}

The author extended over great thanks for Prof. Dr. Ir. Supriharyono, MS and Prof. Dr. Ir. Johannes Hutabarat, MSc, as the promotor and co-promotor, for their time and energy that had been spent to provide any thoughts and inputs for the accomplishment of this scientific work.

\section{Reference}

Arafin, Z. (1993). Distribution, habitat and fishery of lola (Trochus niloticus) in Maluku Waters. Jur. Fak. Per. UNHAS. Makasar, 1(3), 40 - 48.

Armithalingan, C. (1932). Trochus niloticus. Linnin Andaman Waters. Nature CXXX, 1, 98. London.

Castell, L. L. (1997). Population Studies of Juvenile Trochus niloticus on a reef flat on the Northestern Queensland Coast, Australia. Marine Freshwater Research.Auatralia, 47(3), $211-217$.

Colquhoun, J. M., (2001). Habitat preferences of juvenile trochus in Western Australia; Implications for stochk enhancement and assessment. SPC Trochus Information Bulletin. New Caledonia, 7, 14-19.

Crowe, T. P., Dobson, G., \& C. L., Lee. (2001). A novel method for taging animals in complex habitats and its use in research into stock enhancement of Trochus niloticus. Aquaculture, 194, 383-391.

English, S., C. Wilkinson, \& V. Baker. (1994). Survey manual for tropical marine resources $\left(2^{\text {nd }}\right.$ ed). Australia Institute Of Marine Science, Townsville, Australia.390 pp.

FAO. (1992). Information on trochus fishenes in the South Pacific. SPC Trochus Information Bulletin. New Caledonia. 1, 12-15.

Hahn, K.O. (1989). Culture of the Tropical Topshell, Trochus niloticus. In : CRC Handbook of Culture of Abalone and Other Marine Gastropods. CRC Press, Boca Raton, 301-315.

Heslinga, G. A. (1981b). Larva Development, Settlement and Metamorphosis of the Tropical Gastropod Trochus niloticus. Malacologia, 20(2), 349-357.

Indrawan. M., Primack, R. B., \& J. Supriatna. (2007). Biologi Konservasi, Edisi Revisi: Yayasan Obor Indonesia. Jakarta. pp. 625.

Lawrence, C. (1998). Aquaculture in West Australia: Trochus. Department of Fisheries. Retrieved from http://www.aqua/troca

Leimena, H. E. P., T. S. Subahar, \& dan Adianto. (2007). Kepadatan, Biomassa, Dan Pola 


\section{Macrothink}

Journal of Environment and Ecology

ISSN 2157-6092

2013, Vol. 4, No. 1

Distribusi Keong Lola (Trochus Niloticus) Di Pulau Saparua, Kabupaten Maluku Tengah. Berk. Penel. Hayati, 12(73-78).

Leimena, H. E. P. (2002). Potensi pemanfaatan beberapa jenis keong laut (Moluska: Gastropoda). Jur. Hayati, 9(3),97-99.

Moorhouse, F.W. (1932). Notes on Trochus niloticus. Scientific Reports of the Great Barrier Reef Expedition : 1928-1929, Nature, 3, 145-155.

Nash,W. (1985). The biology of Trochus niloticus and its fishery in the Great Barier Reef Region. North Fisheries Research Center. Queensland Australia.210.

Nybakken, J.W. (1992). Biologi Laut: Suatu Pendekatan Ekologi. (Penterjamah: M.Iedman; Koesoebiono; Dietrich; Hutomo; dan Sukardjo). PT. Gramedia. Jakarta. Hal: 459.

Pauly, D. (1980). A Selection of Siple Methods for the assesment of Tropical Fish Stocks. FAO Fish Cire (729): 54.

Ponia, B.O., Terekia, \& T. Taime. (1997). Study of Trochus intriduced to Penrhyn, Cook Islands. SPC Trochus Information Bulletin.New Calidonia, 5,18-24.

Rao, H. S. (1937). On the Habitat and Habits of Trochus niloticus. Linn in The Andaman Seas. Record of The Indian Museum, Calcutta, 39, 47-82.

Republik Indonesia. (2001). Keputusan Menteri Negara Lingkungan Hidup Nomor 04 Tahun 2001 tentang Kriteria Baku Kerusakan Terumbu Karang

Suwartana, A., S. A. P. Dwiono, \& S. Wouthuyzen. (1985). Studi Pendahuluan Tentang pertumbuhan Lola, Trochus niloticus (Moluska, Trochidae) di Alam.Perairan Maluku dan Sekitarnya.BP2SL-P3O LIPI. Ambon:hal 82-86. 